\title{
DETECTION OF THE HEPATITIS C VIRUS IN A POPULATION OF ADULTS
}

\author{
Glauco Danielle Fagundes ${ }^{1}$ \\ Vicente Bonazza \\ Luciane Bisognin Ceretta ${ }^{3}$ \\ Álvaro José Back ${ }^{4}$ \\ Jane Bettiol ${ }^{5}$
}

Fagundes GD, Bonazza V, Ceretta LB, Back AJ, Bettiol J. Detection of the Hepatitis C virus in a population of adults. Rev Latino-am Enfermagem 2008 maio-junho; 16(3):396-400.

The objective of this study was to determine the prevalence of Hepatitis C virus (HCV) in adults from Criciuma-SC and to search factors associated with the viral transmission. Methods: During a health campaign, a questionnaire about factors associated to HCV transmission and tests to detect HCV were applied. A representative sample of the population was considered with 300 voluntaries. Fisher's Exact test, Mann-Whitney and Kappa tests were performed ( $p$ values < 0.05 were considered significant). Results: HCV was detected in 7/ $457(1.53 \%)$ voluntaries. Subjects with positive HCV had a mean of 5.7 (+/- 4.1 SD) sexual partners in the last 10 years, which was significantly higher than those with negative anti-HCV (mean sexual partners 2 +/$2.5 S D)(p=0.01)$. Conclusion: The prevalence of HCV in a voluntary population of adults from Criciuma-SC was high and there was significant association between positive anti-HCV and higher number of sexual partners.

DESCRIPTORS: hepatitis C; prevalence; risk factors; sexual partners

\section{DETECCIÓN DEL VIRUS DE LA HEPATITIS C EN UNA POBLACIÓN DE ADULTOS}

El estudio tuvo como objetivo determinar la presencia del virus de la Hepatitis C (VHC) en adultos de la ciudad de Criciúma-SC y buscar factores relacionados a la transmisión viral. Métodos: en una campaña de salud sobre Hepatitis C fue aplicado un cuestionario sobre factores relacionados a la transmisión del VHC; se realizaron pruebas para detectar el virus. Se estableció, como muestra representativa, la participación de 300 individuos de la población. Fueron aplicadas los pruebas Exato de Fischer, Mann-Whitney y Kappa (con valores significativos de $p<0,05)$. Resultados: La Hepatitis C fue detectada en $7 / 457$ participantes (1,53\%). Los individuos con VHC positivo tuvieron un promedio de 5,7 (+/- 4,1 DE) compañeros sexuales en los últimos 10 años y ese valor fue significativamente más elevado que los que presentaron el resultado de VHC negativo (promedio de 2 compañeros +/- 2,5 DE) ( $p=0,01)$. Conclusión: La seropresencia de VHC en una población voluntaria de adultos de Criciúma-SC fue elevada, habiendo una asociación entre la presencia del VHC y el mayor número de compañeros sexuales.

DESCRIPTORES: hepatitis C; prevalencia; factores de riesgo; parejas sexuales

\section{DETECÇÃO DO VÍRUS DA HEPATITE C EM UMA POPULAÇÃO DE ADULTOS}

O estudo objetivou determinar a prevalência de vírus da hepatite C (HCV) em adultos de Criciúma, SC, e procurar fatores relacionados à transmissão viral. Métodos: em uma campanha de saúde sobre hepatite $C$ foi aplicado questionário sobre fatores relativos à transmissão de HVC e testes de detecção viral. Estabeleceuse 300 participantes como amostra representativa da população. Foram aplicados os testes Exato de Fischer, Mann-Whitney e Kappa (significativos valores de $p<0,05)$. Resultados: hepatite $C$ foi detectada em $7 / 457$ participantes (1,53\%). Indivíduos com HCV positivo tiveram média de $5,7(+/-4,1$ DP) parceiros sexuais nos últimos 10 anos e esse valor foi significativamente mais elevado do que para aqueles com HCV negativo (média de 2 parceiros $+/-2,5 \mathrm{DP})(p=0,01)$. Conclusão: a soroprevalência de HCV em uma população voluntária de adultos de Criciúma, SC, foi elevada, havendo associação entre a presença de HCV e maior número de parceiros sexuais.

DESCRITORES: hepatite C; prevalência; fatores de risco; parceiros sexuais

${ }^{1}$ Physician, M.Sc. in Health Sciences, Faculty, e-mail: gdf@unesc.net; ${ }^{2}$ Undergraduate Medical student; ${ }^{3}$ Faculty; ${ }^{4}$ Ph.D. in Statistics, Faculty. Universidade do Extremo Sul Catarinense, Brazil; 5 Ph.D. in Medicine, Faculty, Universidade do Sul de Santa Catarina, Brazil, e-mail: janebettiol@matrix.com.br 


\section{INTRODUCTION}

Infection by Hepatitis C virus (HCV) is currently one of the most relevant public health problems, due to features such as the long period of asymptomatic infection, which makes subjects not know about the disease and, therefore, not look for special care. Additionally, it can become chronic in up to $85 \%$ of infected people, and it increases the risk for developing severe complications such as liver cirrhosis and liver cancer.

Global Hepatitis C prevalence is $3 \%^{(1)}$, in the American continent it is $1.7 \%^{(2)}$. In Brazil, the prevalence is $1 \%$ to $2 \%$, and a $0.65 \%$ rate is estimated for the South region of the country ${ }^{(3)}$.

As it is a virus mainly transmitted through blood contact, individuals with greater risk are intravenous illegal drug users, hemophiliacs, individuals infected with Human Immunodeficiency Virus (HIV), patients undergoing haemodialysis, people in prisons, as well as those that received blood transfusion before $1992^{(3)}$. Other parenteral ways for contamination are medical procedure, dentist, acupuncture, or tattoos, especially related with cutting or perforating material that can pass the virus from one person to another. Among the non-parenteral forms of Hepatitis $C$ virus transmission sex must be emphasized ${ }^{(4)}$. There is data pointing that monogamous heterosexual couples has a risk to infection ranged from 0 to $27 \%$, where one of the spouses has HCV infection; however, most studies show that the chances for transmission are small or almost null, varying between $0 \%$ and $3 \%{ }^{(5)}$. In-house transmission is often considered and mentioned as a confusing factor when it is related with transmission among couples, because it should be considered that sharing personal hygiene such as disposable razors, tooth brush, nail pliers are important risk factors for $\mathrm{HCV}$ transmission in a household ${ }^{(5)}$.

Regarding the knowledge on the prevalence and risk factors for Hepatitis C, further studies are necessary, because there is still little knowledge about this issue in the general population. There are few population surveys in the South of Brazil demonstrating the prevalence of Hepatitis $\mathrm{C}$ and also about the way virus is transmitted in the population. Most studies identify the frequency of Hepatitis $C$ virus prevalence in blood donors, therefore, not always representative of the general population.
A population based survey can be performed on Criciuma, a city with approximately 180,000 inhabitants, located in the South of Santa Catarina (SC), settled by Italians, Germans, Polish, Portuguese, and Africans and that is an important city in the region. Thus, the objective of this study was to detect the presence of $\mathrm{HCV}$ in a sample of the adult population from Criciúma, taking part of a health campaign on Hepatitis C.

\section{METHODOLOGY}

A sample of 300 adults was estimated. They were participants of a health campaign performed in a public square in the city center of Criciúma on July $25^{\text {th }}, 2005$, where health professionals (nurses, nursing assistants, or medical students) gave orientations regarding Hepatitis $\mathrm{C}$ virus. The campaign lasted over a week with disclosure in the main local means of communication (radio and TV) aiming at making the population aware of the importance of going to health care centers for blood collection to investigate for Hepatitis C, and the possible transmission factors, independently of having a medical condition.

Before blood collection, participants gave their free informed consent. Later, they answered a questionnaire with questions on the reason for being interested in taking part in the campaign, age, gender, marital status, illegal injection drug use, number of sexual partners in the last 10 years, history of blood transfusion, it they use or used tattoos and pierces, and if they had relatives with history of hepatitis.

Material

Ten $\mathrm{ml}$ of blood were collected in dry sterile tubes without anticoagulants using peripheral venous puncture of individuals who voluntarily presented themselves for the serum test to detect antibody against Hepatitis C virus (anti-HCV). Blood collected was stored in a Styrofoam container at $4^{\circ} \mathrm{C}$ until it was sent for processing in the Regional laboratory of Criciuma. In the laboratory it was centrifuged at a speed of $3500 \mathrm{rpm}$ for $5 \mathrm{~min}$ at $25^{\circ} \mathrm{C}$, the supernatant was used to detect $\mathrm{HCV}$; the cell fraction was reserved at $-20^{\circ} \mathrm{C}$ to detect viral ribonucleic acid (RNA) in a posterior stage. 
Anti-HCV detection

Anti-HCV detection was performed with ELISA Kit (Hepanostika HCV Ultra, manufactured by Beijing United Biomedical Co. Ltd, China). Methodology followed the information contained in the manufacturer's guide.

Initially reactive samples were tested in duplicate. Samples which did not react in any of the tests were considered non-reactive for HCV antibodies. Reactive samples in one or 2 tests were considered as possible for HCV antibodies, and then, viral RNA research was performed to confirm virus detection using polymerase chain reaction method (PCR).

Viral RNA detection using PCR

Amplicor Hepatitis C virus test, version 2.0 (ROCHE) was used, it is a qualitative diagnoses test "in vitro", to detect RNA of Hepatitis C virus. Processing the material followed according to the technical guide and in short there are 5 main processes: preparation of the sample, reverse transcription of the target RNA to produce complementary deoxyribonucleic (cDNA), amplification and sequencing of the 269 nucleotides of the $\mathrm{S}^{\prime}$ that did not codify $\mathrm{HCV}$, amplified products with oligonucleotide hybridization probes of the targets and detection of the amplified products connected to the probes with colorimetric determination.

In samples with positive PCR, HCV genotyping was performed for therapeutic reasons.

\section{Statistical Analysis}

To assess frequency of association of variables Fischer's exact test and Mann-Whitney's test were performed, as well as Kappa's Test to assess the correlation coefficient among the variables. Significance level was considered for $p<0.05$ values.

Ethical Aspects

Outcomes of serology and data of the questionnaire were stored in a data bank with only one identification number, to keep individuals' confidentiality and ensuring confidentiality of information.

The project of this study was approved by the Ethical Research Committee at UNESC (process \# 294).

\section{RESULTS}

A total of 457 individuals took part spontaneously in the anti-HCV survey, among them 312 answered the applied questionnaire, and this was considered a sample number that was representative of the population. General features of subjects who answered the questionnaire are presented on Table 1.

Table 1 - Features of individuals taking part in the campaign to assess risk factors for HCV transmission, Criciúma-SC, July 2005

\begin{tabular}{lc}
\hline \multicolumn{1}{c}{ Features } & Frequency (\%) \\
\hline Gender & \\
male/female $(\%$ male) & $162 / 312(52 \%)$ \\
Age & \\
In years (mean \pm standard deviation SD) & $46.8 \pm 14.5$ \\
Marital Status & \\
Married or living with partner & $66.8 \%$ \\
Single & $19.5 \%$ \\
Divorced & $7 \%$ \\
Widow (er) & $6.7 \%$ \\
\hline
\end{tabular}

Anti-HCV detection was positive in 10 of the 457 participants. Among the 10 individuals seropositive for Hepatitis C, seven confirmed at PCR. As virus detection is more sensitive and specific using PCR method, Hepatitis C prevalence was considered in this population was $1.53 \%$, despite seroprevalence of $2.2 \%$. All participants with positive anti-HCV and PCR had answered the questionnaire.

Frequency of affirmative answers on risk factors of the 312 participants answering the questionnaire is presented on Table 2 .

Table 2- Answers to questions on risk factors of individuals with positive $\mathrm{HCV}(\mathrm{HCV}+)$ and negative HCV (HCV -) in Criciúma-SC, July 2005

\begin{tabular}{|c|c|c|c|}
\hline $\begin{array}{c}\text { Risk factors for Hepatitis } \\
\text { C }\end{array}$ & $\mathrm{HCV}+$ & HCV - & $\begin{array}{l}\text { Fisher's } \\
\text { exact test }\end{array}$ \\
\hline $\begin{array}{l}\text { Uses or used intravenous } \\
\text { illegal drug }\end{array}$ & $14.2 \%(1 / 7)$ & $4.2 \%(13 / 305)$ & $p=0.27$ \\
\hline $\begin{array}{l}\text { Underwent blood } \\
\text { transfusion }\end{array}$ & $28.5 \%(2 / 7)$ & $18 \%(55 / 305)$ & $p=0.67$ \\
\hline Has tattoos and/or pierces & 0 & $7.5 \%(23 / 305)$ & $p=1$ \\
\hline $\begin{array}{l}\text { Over } 8 \text { sex partner in the } \\
\text { last } 10 \text { years }\end{array}$ & $57.1 \%(4 / 7)$ & $8.2 \%(25 / 305)$ & $p<0.01$ \\
\hline $\begin{array}{l}\text { Household contact with } \\
\text { Hepatitis }\end{array}$ & 0 & $20 \%(61 / 305)$ & $p=0.35$ \\
\hline
\end{tabular}

Individuals features of subject with positive HCV were also assessed, they are shown on table 3. Mean age of these individuals was 52.6 years old. 
Table 3- Individual features of volunteer subjects with positive HCV in a health campaign in Criciúma-SC, July, 2005

\begin{tabular}{cccccccc}
\hline $\begin{array}{c}\text { Age } \\
\text { (years) }\end{array}$ & Gender & $\begin{array}{c}\text { Marital } \\
\text { Status }\end{array}$ & $\begin{array}{c}\text { Household } \\
\text { contact with } \\
\text { Hepatitis }\end{array}$ & $\begin{array}{c}\text { Blood } \\
\text { transfusion }\end{array}$ & $\begin{array}{c}\text { IV illegal } \\
\text { drug use }\end{array}$ & $\begin{array}{c}\text { Tattoos } \\
\text { and/or pierces }\end{array}$ & $\begin{array}{c}\text { Number of sexual } \\
\text { partners in the last } \\
\text { 10 years }\end{array}$ \\
\hline 41 & M & Single & No & No & Yes & No & $8+$ \\
in the campaign
\end{tabular}

$\mathrm{F}=$ female, $\mathrm{M}=$ male, $\mathrm{STD}=$ sexually transmitted disease

Because significant difference was seen in the frequency of the answer "had over 8 sexual partners in the last 10 years" among positive and negative HCV individuals $(p<0.01)$, a statistical analysis was performed comparing the number of sexual partners between these groups. To calculate, number 9 was used when the answer was "over 8 partners in the last 10 years", since participants did not have another numeric option for this question. Thus, again a statistically significant difference was obtained $(p=$ 0.010; Mann-Whitney's test) in the number of sexual partners among individuals with positive HCV (mean $5.7 \pm 4.1$ partners) and negative $\mathrm{HCV}$ (mean $2 \pm$ 2.5), as shown in figure 1. Furthermore, correlation was seen between the number of sex partners and the presence of HCV ( $k=0.193 ; p<0.001$; Kappa's test).

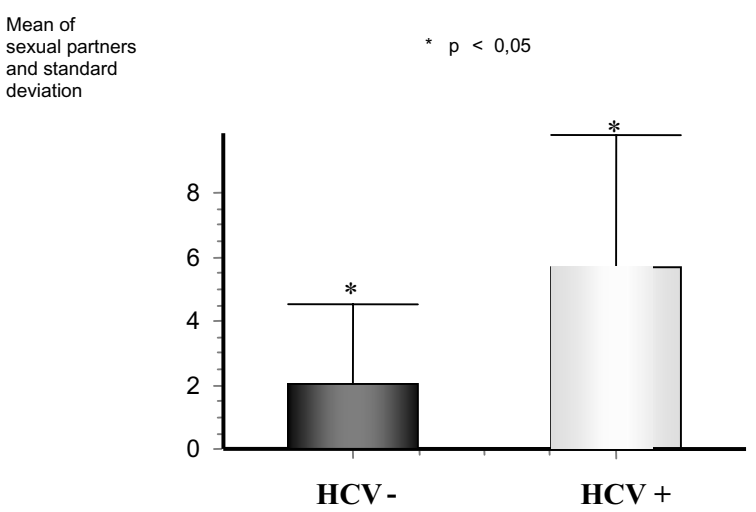

Figure 1 - Mean value of sex partner and correlation with HCV detection during a campaign performed in Criciúma-SC, July 2005

\section{DISCUSSION}

Although anti-HCV prevalence was $2.2 \%, \mathrm{HCV}$ prevalence was $1.53 \%$ in adults from Criciuma taking part in a health campaign on Hepatitis C. This outcome is compatible with the National level of $1-2 \%$, but it is above the level estimated for the South region which is $0.65 \%$, according to a survey conducted in blood donors by the Brazilian Society of Hepatology ${ }^{(3)}$. Our study was urban population-based, not directed to risk group. However, many of the participants wanted to know their serum state possibly because they considered themselves in risk of having the virus, that is the reason for the high frequency of the answer "doubt" among HCV positive individuals, when the question was "reason for taking part in this campaign". So, there may have been an involuntary selection of these individuals. This may be a partial explanation for the increased prevalence in this population compared to that of the South region, observed in the previously mentioned study. On the other hand, a survey conducted in the State of Santa Catarina with blood donors, revealed that the positivity anti-HCV was $0.31 \%$ to $0.38 \%$ between the years of 1999 and 2001 , and in Criciuma results were $0.58 \%, 0.39 \%$ and $0.40 \%$ in the years 1999, 2000 and 2001, respectively ${ }^{(6)}$. Blood donors are supposed to be healthy and probably do not adopt risk practices such as illegal intravenous drug use or even having many sex partners, because of that, a lower prevalence of positive-HCV is expected in this population.

In the present study there was a correlation between HCV transmission and having several sex partners in the last 10 years. As previously speculated, if individuals considered themselves at risk, this was probably the number of partners. Among the 7 positive HCV individuals, 4 said they had many sexual partners.

A great part of volunteers with the virus took part in the study because they feared they had been contaminated. This bias may influence results; however, it is hard to be excluded in such a study. Regardless of this, correlation between positive HCV 
and number of sexual partners should be highlighted as an index that sex transmission was the HCV infection via in this group. Sexual transmission is not considered a predominant contagious factor ${ }^{(7)}$, however some studies indicate large number of sexual partners as a risk factor ${ }^{(8)}$ and in some cases it is associated with men who have sex with other men ${ }^{(9)}$. Subjects with positive HCV did not report having sex with other men. This information could cause embarrassment and it is usually hidden or denied by interviewees. In fact, none of the 312 participants answered yes to this question. Four of the $7 \mathrm{HCV}$ individuals were married and among them, 2 reported having several sex partners in the last years and none of them revealed household contact with Hepatitis. Among heterosexual, monogamous couples where one of the spouses has HCV infection, most studies state that chances of transmission are low, and the risk referred varies from 0 to $27 \%$. This index takes into consideration factors that may be related with transmission such as sharing personal hygiene objects between the couple ${ }^{(5)}$. Although this consideration is more valid to monogamous couples, it should not be excluded for individuals with several partners.

The study did not present association between positivity to Hepatitis $\mathrm{C}$ and illegal intravenous drug use, although this is a well determined risk factor in the literature ${ }^{(4,7)}$. Similarly the question about men who have sex with other men, the question about the use of illegal drugs usually causes embarrassment

\section{REFERENCES}

1. Wong $\mathrm{T}$, Lee SS. Hepatitis C: a review for primary care physicians. CMAJ. February 2006; 174(5): 649-59.

2. World Health Organization. Hepatitis C - global prevalence (update). Wkly Epidemiol Rec 1999; 74:425-7.

3. Ferreira CT, Silveira TR. Viral Hepatitis: epidemiological and preventive aspects. Rev Bras de Epidemiol 2004; $7(4): 473-87$

4. Strauss E. Hepatite C. Rev Soc Bras Med Trop 2001; 34(1):69-82.

5. Cavalheiro NP. Sexual transmission of Hepatitis C. Rev Inst Med Trop São Paulo 2007; 49: 271-7. and there is no spontaneity to answer that. Thus, $4.5 \%$ of the total population and only one of the 7 subjects with positive HCV answered yes to this question. However, Santa Catarina is one of the Brazilian States with higher number of intravenous illegal drug users and HIV, and one third is infected this way ${ }^{(10)}$.

The use of tattoos and piercing was not associated with HCV in this study, as well as blood transfusion. However, data from the literature point out that these are risk factors that may be associated with Hepatitis C, especially blood transfusions performed up to the beginning of the $90 \mathrm{~s}^{(4)}$. None of the subjects with HCV referred use of tattoos and/or Pierce, and only one of them underwent blood transfusion which may have been the transmission way since there were no other risk factors in this individual.

\section{CONCLUSION}

Hepatitis C prevalence in Criciuma-SC was high $(1.53 \%)$ in comparison with the South of Brazil, and HCV presence was associated with a report of a higher number of sexual partners. Although these results may be influenced by the study condition, it calls our attention the correlation between having many partners and the presence of detectable HCV, a condition that could be avoided by a simple measure, such as the use of condoms.

6. Rosini N, Mousse D, Spada C, Treitinger A. Seroprevalence of HbsAg, anti-HBc and Anti-HCV in Southern Brazil, 19992001. Braz J Infect Dis 2003; 7(4):262-7.

7. NIH Expert Panel. NIH Concensus Statement on Management of of Hepatitis C: 2002. NIH Concens Stat Sci Statements 2002;I9:I-46.

8. Mesquita PE, Granato CF, Castelo A. Risk factors associated with hepatitis C vírus (HCV) infection among prostitutes and their clients in the city of Santos, São Paulo State, Brazil. J Med Virology 1997; 51(4):338-43.

9. Gambotti L, Batisse D, Colin-de-Verdiere N, DelaroqueAstagneau, Desenclos JC, Dominguez S, et al. Acute hepatitis $C$ infection in HIV positive men who have sex with men in Paris, France, 2001-2004. Euro Surveill. 2005; 10(5):115-

10. Brazilian Ministry of Health - Brazilian National STD and AIDS Programme. Populações: Usuários de drogas (de um modo geral) e usuários de drogas injetáveis. Available from: URL: http://www.aids.gov.br/final/prevencao/udi.htm. 